Pecvnia, 1 (2005), pp. 201-227

\title{
Rentas, gastos y administración de la Obra y Fábrica de la catedral de Toledo en la primera mitad del siglo XVI
}

\author{
Susana Villaluenga De Gracia \\ Francisco Javier Quesada Sánchez
}

La Obra y Fábrica de la catedral de Toledo afrontaba las obras, acondicionamiento y ornamentación del templo desde el momento de su ubicación definitiva en el emplazamiento que antes de la Reconquista ocupaba la antigua mezquita de la ciudad. A este organismo dirigido por el prelado y que crecía auspiciado por el cabildo, le correspondía para financiar su actividad la recaudación de un cúmulo importante de rentas de diferente naturaleza: rentas de los inmuebles adscritos a su patrimonio, excusados de Obra, aliceres, mandas y demandas e ingresos extraordinarios. La envergadura de estas rentas y una sabia gestión apoyada en un sólido aparato administrativo, forjado en base a la experiencia, venía a garantizar un sabio empleo de estos recursos financieros. La aplicación de los mismos se materializaba, no sólo en atender los afanes de la vida cotidiana, sino en acometer imponentes obras artísticas que hoy en día invaden todos los rincones del templo catedral. De hecho en la primera mitad del siglo XVI, asistimos a uno de los períodos de mayor esplendor artístico en la
The Work and Factory of the cathedral of Toledo confronted the works, the arrangement and ornamentation of the temple from the moment of its definitive location in the site that before the Reconquest of Spain it had occupied the old mosque of the city. To this organism directed by the prelate and that grew favoured by the chapter, it corresponded to finance its activity, the collection of an important heap of rents of several nature: rents of the properties attached to its patrimony, excusado of Work, aliceres, executrix bequests and demands and extraordinary revenue. The span of its rents and a wise administration supported in a solid administrative apparatus, wrought based on the experience, it came to guarantee a sage employment of these financial resources. Its application was materialized, not only in assisting the daily chores, but in carrying out imposing artistic works that today invades all the corners of the temple cathedral. In fact in the first half of the XVI century, we attended 
catedral de Toledo, coincidiendo con una importante bonanza económica.

Palabras clave: Historia de la Contabilidad, Catedral de Toledo, Obra y Fábrica. one of the periods of better artistic splendour in the cathedral of Toledo, coinciding with an important economic prosperity.

Key words: History of the Accounting, Cathedral of Toledo, Work and Factory.

\section{LA OBRA Y FÁBRICA DE LA CATEDRAL DE TOLEDO}

A lo largo del tiempo la Obra y Fábrica de los templos se venía haciendo cargo de la construcción y el mantenimiento del edificio donde se daba cobijo al culto. Sus funciones, por tanto, abarcaban dos ámbitos: la construcción, a la que se refería el término Obra; y el mantenimiento y la supervisión de los instrumentos y elementos destinados al servicio religioso, la Fábrica. En este punto, era la Fábrica, dedicada al culto, el nexo fundamental que unía este organismo con el cabildo.

La Obra y Fábrica dependía de los cabildos catedralicios. En el caso de la Catedral de Toledo está dependencia se manifestaba fundamentalmente en el papel desempeñado por el cabildo en la elección de los cargos. Por lo que cabe al plano económico, la Obra y Fábrica mantenía un organigrama administrativo y de dirección propio, encaminado a la gestión de un patrimonio privativo e independiente que le proporcionaba un importante cúmulo de rentas. Además, a pesar de comprender dos conceptos que aunaban cometidos diferentes y perfectamente definidos, Obra y Fábrica, ambos conformaban el objeto de un organismo económico conjunto, conocido también simplemente como Obra.

Como decimos, el sostenimiento de la Obra y Fábrica toledana se asentaba en la recaudación de un importante número de rentas. Entre todas las rentas destinadas a financiar las actividades de este organismo, eran los excusados de Obra, el segundo mejor diezmo de cada parroquia, el recurso de mayor importancia. A estos excusados de Obra cabía añadir las rentas de las posesiones adscritas a la entidad, los aliceres, las mandas y demandas testamentarias, etc. Todas estas rentas contribuían a financiar un conjunto de actividades, entre ellas algunas de una gran importancia artística de las que dan cumplida cuenta los vestigios arquitectónicos, escultóricos y pictóricos, presentes en el edificio catedral. Cuestión esta última que resulta, a la vez, el medidor básico y más acertado para comprender las circunstancias económicas por la que venía atravesando el organismo. Es decir, por lógica, los períodos de mayor prestancia artística venían a coincidir con los períodos de mayor opulencia económica. 
Desde la Obra y Fábrica toledana se afrontaban las obras, acondicionamiento y ornamentación del templo catedral desde el momento de su ubicación definitiva en el emplazamiento que antes de la Reconquista ocupaba la antigua mezquita de la ciudad. Asimismo, haciendo un poco de memoria histórica en este sentido, con la Reconquista, en tiempos del rey Alfonso VI (1085), la antigua mezquita se consagró al culto cristiano ${ }^{1}$, aunque fue en tiempos de Fernando III y del obispo Rodrigo Jiménez de Rada ${ }^{2}$ en el siglo XIII, cuando se decidió derribar el antiguo templo y construir, en el mismo lugar, y auspiciados por los recursos financieros emergentes; un templo de mayores dimensiones que se acogiera a las necesidades de una población cristiana cada vez más numerosa. Esta nueva construcción iniciada el 14 de agosto de 1227, tendría su fin en enero de 1493, con el cerramiento de las últimas bóvedas (Sixto Ramón Parro 1857: I, 63). Hasta este momento y desde su establecimiento, la Obra y Fábrica iría aumentando sus responsabilidades y cometidos, fruto de las nuevas necesidades.

La organización de la Obra y Fábrica en su conjunto atendía a los requerimientos de la catedral, y la titularidad de dicho gobierno, en este caso, correspondía al prelado. El prelado se encargaba, con la anuencia del cabildo, del nombramiento del conocido como canónigo obrero u obrero mayor, entre los canónigos del cabildo catedral ${ }^{3}$. Sobre el canónigo obrero, recaían las labores de administración de la hacienda de la Obra y Fábrica, siempre vigilado y asesorado por los visitadores, nombrados por el obispo a tal efecto. De esta forma, el obrero mayor se puede decir que ejercía las labores de representación y de gobierno de la Obra y Fábrica por delegación del prelado. Éste gestionaba el funcionamiento de este organismo, vinculado, en un sentido u otro, a la vida diaria de la catedral y era el responsable directo de su correcto funcionamiento. Funcionamiento que se articulaba, a su vez, de forma más concreta en un conjunto de

1 En concreto, los historiadores hablan de que dicha consagración tuvo lugar el 25 de octubre de 1087, dedicada a Santa María.

2 Tal como señala Pedro de Alcocer (1554, fol.LXVIIIv-LXIXr): "...y no solamente este venerable Arçobispo hizo estas Sanctas obras que auemos dicho: mas el fue el que con mayor instancia procuro que esta Sancta Iglesia (que estaua en forma de Mezquita, ansi como los Moros la pusieron al tiempo que tiranizaron esta cibdad) y se derribasse por el suelo, y se hiciese otra de mas rica y suptuosa obra: como oy esta según adelante diremos."

3 El obrero era nombrado entre los canónigos y dignidades. Su elección podía corresponder al Arzobispo que contaba para ello, normalmente, con el consentimiento del Cabildo, y en este caso sería un nombramiento indefinido. En caso de que el nombramiento fuera capitular, el canónigo obrero ejercía sus funciones durante un año (Fernández Collado 1998: 30). 
cargos y oficios, jerarquizados y agrupados en torno, por un lado, a la Obra; y por otro, a la Fábrica.

Entre el personal de la Obra, cabe hablar de dos tipos de cargos en función a la naturaleza de las labores que les ocupaban. En este sentido, tenemos los conocidos como cargos supervisores y los cargos ejecutores ${ }^{4}$. Por lo que respecta a los primeros, conviene hacer mención, en primer lugar, al maestro de obras, responsable de la ejecución e inspección de las construcciones; al aparejador, que asistía y hacía cumplir a los peones, bajo penalización, las ordenes del maestro de obras; y al sobrestante, encargado de apuntar durante la mañana y la tarde la asistencia de los oficiales y peones de la Obra, información a tener en cuenta para fijar las remuneraciones posteriores, correspondientes a cada uno de ellos. Sobre los segundos cargos, denominados ejecutores, mencionamos el albañil, que asistía e informaba al sobrestante de las ausencias de los peones; y los peones y canteros.

Por lo que respecta a la Fábrica, cabe destacar el clavero, encargado de custodiar y mantener, en los aposentos del piso superior del claustro, los materiales de la Fábrica y los utensilios del culto, además de instrumentos, herramientas y materiales de uso en la catedral. Junto al clavero, podemos mencionar al tenedor de materiales, confiado del reparto diario de las herramientas y utillaje y de los elementos necesarios para la construcción; y otra serie de cargos vinculados a las labores de iluminación del edificio catedral, como el lamparero, el encendedor de la cera; a los trabajos de vigilancia, entre los que destacamos: el portero, alcaide de la torre, guardas eclesiásticas y seglares, guarda de la noche, el perrero, etc.; y por último, a las funciones de mantenimiento diario: campanero, encargado de los libros del coro, barrenderos, lampareros, relojero, jardinero, etc.

Además de los hasta aquí mencionados, existía un conjunto de oficios contratados por la Obra y Fábrica para la realización de trabajos puntuales entre los que cabe mencionar: herreros, pintores,

\footnotetext{
4 Las funciones de todos ellos aparecen especificadas en el trabajo de Laura Santolaya Heredero, La Obra y Fábrica de la Catedral de Toledo a finales del siglo XVI, Edición patrocinada por la Caja de Ahorro Provincial de Toledo, Toledo, 1979. Por esta razón, no hemos entrado en más detalle al respecto. No obstante, hay que señalar que la autora, a pesar de tener como objeto de estudio el siglo XVI, para esta recopilación se basa en unas órdenes dictadas conforme a un auto de visita realizado por D. Francisco Zapata, el 16 de diciembre de 1627 y a dos autos de visita elaborados por D. Antonio de Velasco y el licenciado don Pedro Zamora Hurtado, en 25 de enero y 29 de noviembre de 1644. La documentación figura en el Archivo Diocesano.
} 
bordadores, plateros, cordoneros, etc. A todos ellos, es necesario añadir otra serie de personajes que figuran en los registros contables de este período, dedicados a labores de culto: cantores, maestros de capillas, músico de sala, seises, el personaje encargado de afinar los órganos o el de poner los libros en el coro, etc.

Es en el siglo XVI, cuando la grandiosidad artística y económica de la Obra coincide con el mayor número de personal a su cargo. No obstante, en años posteriores se producirían una considerable mengua, achacada a la reducción de las nóminas y al reparto de nuevas responsabilidades vinculadas al culto entre la Fábrica y el cabildo (Heredero 1979: 41).

Sin embargo, tal como hemos reconocido, el siglo XVI constituyó en su mayor parte, una época de esplendor por lo que respecta a las labores de la Obra y Fábrica de la catedral de Toledo. En esta época se acometieron un importante número de obras artísticas en el interior del templo catedral. Entre estas obras artísticas merece destacarse, el acabado, en 1524, de la custodia toledana del orfebre Enrique de Arfe, encargada por el Cardenal Cisneros, y en la que empleo el oro de las nuevas posesiones americanas; la capilla Mozárabe que encargó el cabildo a Enrique Egas a principios del siglo XVI, siendo también de principios del siglo XVI las pinturas que decoran el interior, realizadas por Enrique de Borgoña, así como las rejas exteriores de Juan Francés, el mayor maestro rejero de finales del siglo XV y principios del XVI, terminadas en 1524; el retablo plateresco de la capilla de San Eugenio de 1517 del maestro holandés Copín de Holanda; las tallas de los brazos, respaldos y asientos del coro, comenzadas en 1539 y terminadas en 1544; el retablo del Altar Mayor de la Catedral de finales del siglo XV y principios del siglo XVI en el que trabajaron los más importantes maestros europeos de aquel tiempo; el diseño plateresco que Covarrubias hizo para la puerta de la Presentación de la Catedral en 1536; y además de otras tantas obras. Todas las obras mencionadas, muestran, sin embargo, la enorme profusión desplegada por la Obra y Fábrica de la catedral toledana en este tiempo. Profusión que, sin duda, está directamente relacionada con su abundancia económica.

\section{LOS RECURSOS FINANCIEROS}

Tal como hemos venido insistiendo, la prodigalidad artística que desarrolló la Obra y Fábrica de la catedral de Toledo durante el siglo XVI, está íntimamente relacionada con su magnitud económica. En este 
sentido, la Obra manejaba un cúmulo importante de rentas de diferente procedencia. Por un lado, y en orden a su importancia cuantitativa, las rentas procedentes de los denominados excusados de Obra y de los terzuelos, rentas procedentes de lugares sujetos a la jurisdicción de las órdenes militares; $y$, por otro lado, las rentas originadas por la explotación de los bienes inmuebles adscritos a su patrimonio. Además, la Obra y Fábrica se nutría de ingresos de aliceres, juros, tributos, mandas y demandas; así como de los ingresos que conformaban el denominado recibo extraordinario, en el que se incluían donaciones y limosnas, y otros importes entregados a la Obra con carácter circunstancial, de los que se hacía cargo, junto con los demás ingresos, al denominado receptor de la Obra. Sin embargo, eran, de todas las remesas recibidas, las copias de excusados las que representaban la mayor fuente de ingresos con la que se financiaba la Obra y Fábrica ${ }^{5}$.

\section{Las Rentas de las Posesiones}

La Obra y Fábrica contaba con un número importante de bienes raíces de naturaleza rústica y urbana que explotaba en favor de sus intereses económicos. Así, las rentas procedentes de estas posesiones se obtenían, fundamentalmente, a partir de un sistema de aprovechamiento o explotación basado en el arrendamiento o en el censo. Política, por otro lado, general en este tipo de instituciones, donde imperaba, eso sí, la tendencia generalizada a la conservación del patrimonio existente y a su engrandecimiento con las adquisiciones o permutas de otras propiedades.

En relación a las posesiones de la Obra y Fábrica hemos obtenido una relación completa de las diferentes propiedades que permanecían adscritas al patrimonio de la Obra y Fábrica, tomando como base los libros de cuentas catalogados en el Archivo Capitular y relativos a la Obra y Fábrica. En concreto, la fuente documental es el apartado inicial del conocido como libro de Obra, en el que se tomaba registro de los ingresos (cargo) y gastos (descargo) referidos a la Obra y Fábrica toledana. Pues bien, en el apartado detallado del cargo era donde se reconocían los ingresos que devengan cada una de las posesiones, junto a la descripción de las mismas y el régimen de explotación. Por esta razón, hemos podido

5 El propio Ricardo Izquierdo Benito (1981) reconoce que la cuantía de los Obra y Fábrica toledana ya en la Edad Media. 
saber que la Obra y Fábrica de la catedral de Toledo en la primera mitad del siglo XVI, mantenía un conjunto de propiedades, de diferente naturaleza, adscritas a su patrimonio, explotadas en régimen de arrendamiento o censo. Este patrimonio permanecía prácticamente inalterable a lo largo de los diferentes años, tal como se desprende de la comparación de la información que contienen los diferentes libros de Obra ${ }^{6}$, de los que existe una importante base documental ${ }^{7}$.

Como decimos, estas correlaciones nos llevan a constatar la escasa variación del patrimonio inmobiliario de la Obra y Fábrica. Por otra parte, situación nada extraña si tenemos en cuenta la tipología de la política económica de este y otros organismos de las mismas características, encaminados a la conservación del inmovilizado y a la transformación de esta riqueza en renta ${ }^{8}$.

A pesar del importante número de posesiones, rescatado de los libros de Obra, en ningún caso resulta equiparable a las propiedades del otro organismo económico catedralicio, el cabildo. Por estos documentos sí sabemos que la Obra y Fábrica contaba con algunas dehesas y tierras de labor; y un número superior de bienes urbanos, en su mayoría localizados en los diferentes barrios y colaciones de la ciudad de Toledo.

A finales de la primera mitad del siglo XVI la Obra y Fábrica toledana mantenía en propiedad la dehesa de Barciles que se arrendaba de 8 en 8 años; la dehesa de corralejo, que se explotaba en régimen de

6 Aún así, esta afirmación puede resultar complicada, si tenemos en cuenta el hecho de que, en ocasiones, las rentas de estas posesiones aparecieran consignadas en el cargo con diferente grado de detalle. Es decir, en unos casos las rentas de arrendamientos o censos aparecían referidas a cada una de las propiedades arrendadas o sujetas a censo; y en otros casos, se expresaba el monto total de lo que importaba la renta referida a todas las casas de una colación o barrio. Este hecho podría dificultar la comparación de las rentas concretas a efectos de cualquier estudio sobre la evolución detallada de las mismas, ante la falta de unificación de criterios al respecto en el registro original.

Esta abundancia ha dado incluso nombre al Catálogo del Archivo Capitular que incluye además del fondo de Obra, el de mayordomía y apuntación (Torroja 1977: 12). La razón que podíamos achacar a esta buena conservación de los libros de Obra, no cabe la menor duda, que podría ser la inserción en estos libros del documento de rendición de cuentas que daba el receptor. Es decir, la inclusión de la carta cuenta del receptor en los libros de Obra, facilitó la conservación de los mismos a lo largo del tiempo, tal como ocurre en otros documentos de otras receptorías. Pues este documento era vinculante de la labor del receptor y constituía un elemento probatorio de primer orden, de ahí el interés de su conservación.

8 Entendiendo por estos dos conceptos lo que entiende Francisco Javier Quesada al tratar la teoría del patrimonio de la empresa (1995: 111). Así, el término de renta atiende a la idea de flujo o corriente y constituye el conjunto de bienes y servicios generados por el sujeto económico en el trascurso de un período de tiempo. Por el contrario, riqueza acoge la idea de stock, es decir, lo componen todos los bienes, derechos y obligaciones capaces de uso en el proceso productivo. 
arrendamiento por vidas; un tributo de unas casas en la parroquia de San Juan de la Leche; el tributo que devengaba un censo que había sobre el mesón de los paños que pasó al Monasterio de Santo Domingo el Real; el tributo de unas casas junto a San Eugenio, de las que se obtenían ciertas cantidades por su arrendamiento; el tributo de unas casas sobre el callejón del mesón de San Eugenio; la heredad de Benalhabia que se arrendaba por vidas; otro tributo de unas casas que estaban juntas en San Eugenio; el tributo perpetuo sobre unas casas en la Parroquia de San Román, junto al Hospital de San Andrés; el tributo perpetuo sobre unas casas en la parroquia de San Andrés; el tributo de unas casas en la Plazuela del Barrio de Caleros; el tributo de unas casas en la Torre de Abades; el tributo de unas casas en Alpicazuelo; el tributo de dos pares de casas en la Plaza de la Cabeza; el tributo anual sobre unas casas en las que comían los pobres, que compró Cisneros; el tributo perpetuo sobre unas casas que tenía en la Magdalena; el tributo sobre unas casas en la parroquia de San Vicente; dos pares de casas que tenia la Obra en la calle de la Chapinería; el tributo sobre unas casas junto al Alcazar de Toledo, que solían ser de Miguel Podador que pertenecían a la parroquia de San Miguel, y fue el tributo que dejo el canónigo Antonio Ruiz para la capilla de Santa Leocadia; y el tributo sobre unas posesiones de Francisco Pizarro en la Villa de Viruela.

Además de estas rentas obtenidas de censos y arrendamientos, se incluían las rentas del diezmo de Rodillas; ciertas cantidades que cobraba la Obra de la Capilla de San Pedro por el aceite que la Obra daba cada año para las lámparas de la capilla; ciertos maravedíes que deán y cabildo daban cada año por el reparo de la Capilla del Coro de don Pedro González de Mendoza; y otras cantidades que daba el refitolero para el reparo de la capilla de don Juan de Sazedo, Arcediano de Alcaraz. De la misma forma, la Hermandad de racioneros debían aportar aceite 9 para las lámpara del coro que ardía de día y de noche, según las indicaciones del Obrero y los visitadores.

Todas las rentas procedentes de estas propiedades figuraban en el libro de Obra bajo el título general de "Posesiones". El concepto más importante de esta partida era, sin lugar a dudas, la referida a los bienes urbanos ubicados en la ciudad. La explotación de estos bienes, tal como hemos señalado más arriba, era el arrendamiento o censo.

9 Esta aportación en aceite se valoraba al precio de mercado de la arroba de aceite de ese mismo año en el que se hacía el cargo, y se incorporaba al monto total. 
El arrendamiento comenzaba a ejecutarse justo en el momento de vacar el anterior. Era al vencimiento, cuando el notario del cabildo mandaba a una persona para poner cédulas, como era costumbre, donde se creía que las posesiones podrían ser arrendadas, e informar así del hecho a los interesados, así como de la inminente celebración del remate. Tras la celebración del remate, se adjudicaba el arrendamiento y posteriormente se firmaba el contrato ante el notario, tal y como era costumbre también para las posesiones del cabildo. A tenor de este contrato, además de las obligaciones habituales a las que se comprometía el arrendatario, lo hacía pecuniariamente, debiendo entregar una cantidad anual en dinero que era efectiva por tercios, y una cantidad en gallinas por el día de Todos los Santos.

\section{Las Rentas de los Excusados de Obra}

Junto a las rentas que devengaban las posesiones adscritas a la Obra y Fábrica de la Catedral de Toledo, este organismo se beneficiaba de las rentas procedentes de los denominados excusados de Obra, constituidos por el importe del segundo mejor diezmo de cada parroquia nombrado por el cura. Este derecho de cobro era explotado, generalmente, en régimen de arrendamiento, aunque podía hacerse en fieldad ${ }^{10}$.

Los excusados era la remesa, sin duda, más importante del cargo que conformaba la cuenta de la Obra. Estas rentas procedentes de los excusados de Obra se distribuían a lo largo de los diferentes lugares del arzobispado de Toledo. La relación que exponemos a continuación referida a la recaudación hecha de los diferentes lugares por arciprestazgos se ha obtenido de un libro que atendía a la denominación de libro de excusados ${ }^{11}$, donde se detallaban los pormenores de los remates, arrendamientos y las recaudaciones de estos tipos de diezmos.

Por la información contenida en el libro de excusados, y cuyos datos se repiten en el cargo inicial del libro de Obra, donde se hace un

10 El sistema de cobro era en fieldad, cuando la recaudación se realizaba directamente por personal del Obra. Esta fórmula de fieldad se consideraba para el caso de que el sistema de arrendamiento no fuese rentable, en función a que las pujas no hubiesen alcanzando los niveles previstos, o existiesen rentas de por sí poco rentables para el arrendamiento.

11 Así, si consideramos la información contenida en el libro de excusados de 1536-1549 (A.C.T, OF-366), podemos decir que de forma explícita en él se encuentran contenidos los importes de los remates de las distintas rentas de excusados para los diferentes años, además de los correspondientes contratos de arrendamiento firmados por las partes en presencia del notario del cabildo, así como los traspasos de los arrendamientos en casos de que procedieran. 
resumen de esto; sabemos que la Obra y Fábrica obtenía rentas de excusados procedentes de los arciprestazgos de La Guardia, Ocaña, Illescas, Canales, Rodillas, Montalbán, Talavera, Maqueda, Escalona, La Vicaria de La Puebla, Calatrava, Alcaraz, Guadalajara, Alcalá, Talamanca, Uzeda, Buitrago, Hita, Brihuega, Zorita y Almoguera, Madrid, Los Seis Lugares del Real y Los Cinco Lugares de Valdelozoya. De cada uno de estos arciprestazgos obtenía el segundo mejor diezmo. Estas rentas de diezmos se daban en puja en presencia del notario, como se acostumbraba con el resto de las rentas. De tal forma, que a la puja más alta se daba concesión en arrendamiento de dicha renta.

El arrendamiento estaba sujeto a una serie de requisitos que aparecen incluidos en algunos de los libros de excusados que hemos podido estudiar ${ }^{12}$. Entre estos requisitos, básicamente, figuraba el de que los arrendadores tomaban las rentas a riesgo y aventura, y se comprometían a hacer efectivos al receptor de la Obra dos pagos: por Navidad y por Pascua de Resurrección. Dichas cantidades debían ser puestas y pagadas en la ciudad de Toledo en manos del mencionado receptor, pasando este último, en caso de impago, a declarar la quiebra y a proceder en consecuencia según los términos fijados en su contrato.

\section{Las Rentas de los aliceres}

Otra de las partidas de ingresos atribuible a la cuenta de la Obra y Fábrica era la surgida de los aliceres. Los aliceres eran las cantidades procedentes de los traspasos de los arrendamientos, y constituían normalmente una parte de la renta, también se denominaban por esta cuestión décimas de traspasos. Así, procedente de los traspasos de las rentas, la Obra y Fábrica obtenía como ingresos ciertas cantidades que se recogían a tal efecto en la partida consignada expresamente en el cargo del libro de Obra con el título de "alizeres".

12 En concreto, nos referimos a lo que se dice sobre ello en el libro de excusados de 1536-1549: "Registro de las rentas de los escusados de la Santa Iglesia de Toledo..." (A.C.T, OF366), donde aparece un apartado dedicado a las "Condiciones con que se arriendan e san de rematar de todo remate las rentas de los escusados nombrados para la Obra de la Sancta Iglesia de Toledo del fruto de este presente año de quinientos e treynta e siete años son las siguientes" (fol.28r-28v). Por lo que se consigna en estas condiciones sabemos que se vinieron a dar el 5 de mayo de 1537, pregonadas por el pertiguero, Juan de Najara, en presencia del notario del cabildo, Juan de Mudarra; el canónigo obrero, Diego López de Ayala; y los visitadores, Bernabé de Mediana y Pedro de la Peña. El contenido de estas condiciones van dirigidas a los arrendadores de estas rentas de excusados, y, por tanto, se puede ver con mayor profundidad al analizar los libros de excusados de la Obra y Fábrica. 
A pesar de atribuírsele a priori escasa importancia, las rentas de aliceres venían a suponer una parte nada desdeñable del cargo de la cuenta de Obra, o de los ingresos por rentas de los que se nutría esta institución. Esta cantidad que, según se venía a señalar en el asiento referido a esta partida, se le cargaba al receptor de los aliceres que importaron las rentas del año al que se referían y que a finales de la primera mitad del siglo XVI fueron del orden de 30 por millar ${ }^{13}$ (A.C.T, OF-831, fol.5v).

Las Rentas de las Copias de Excusados de la Ciudad de Toledo

Además de las rentas de los excusados procedentes de los distintos lugares del arzobispado de Toledo, sobre el que la Obra tenía reconocido un derecho de cobro; este organismo recibía también las rentas de los excusados procedentes de lo que importaba la copia en las diferentes parroquias de la ciudad de Toledo del fruto de cada año. Esta partida aparecía normalmente en el libro de Obra, de forma independiente al resto de las copias de excusados que recaudaba la Obra, bajo el título "Copias de la ciudad". En estas copias se contenían los excusados que debía cobrar el receptor de la Obra a ciertas parroquias de Toledo. Entre estas parroquias estaba la de San Andrés, San Bartolomé, San Cebrián, San Cristóbal, San Ginés, San Juan Bautista, San Isidro, San Justo, Santa Leocadia, San Lorenzo, San Lucas, San Marcos, Magdalena, San Miguel, San Nicolás, Santa Olalla, San Román, San Salvador, Santiago del Arrabal, Todos Los Santos, Santo Tomé y San Vicente. Los excusados de estas parroquias se cedían, generalmente, en el mismo régimen de explotación que se venía haciendo con los demás excusados de la Obra; y eran recaudados en última instancia por el receptor, a quien se le recibían posteriormente en contra en la cuenta que éste mantenía con la Obra y Fábrica.

\section{Las Rentas de las mandas y demandas}

Bajo este concepto se registraban otra de las partidas que formaba parte del total del cargo que se tomaba al receptor general de la Obra, y que figuraba con el título expreso de "mandas y demandas". En este apartado, por tanto, se incluían los ingresos procedentes de las

13 Es decir un $3 \%$, siguiendo las indicaciones que al respecto da José María González Ferrando sobre los tipos de interés aplicados en las ferias castellanas del siglo XVI (González Ferrando 1998: 378). 
mandas o donaciones testamentarias y de la limosna recaudada en beneficio de la Obra, respectivamente. El contenido de este último concepto, lo constituía la cuarta parte de lo recaudado en todo el arzobispado en favor de monasterios y hospitales, y que tomaba la Obra como promotora de la petición (Heredero 1979: 96).

Del manejo de estas rentas, de su recaudación y distribución, se ocupaba el receptor de la Obra, tomándosele posteriormente cuenta y razón en el cargo y descargo de la cuenta, respectivamente. A este respecto, y como es lógico pensar, la distribución de las cantidades correspondientes a esta limosna aparecería en alguna de las partidas del descargo del mismo libro, donde se daba acogida, a tal efecto, a los gastos de la Obra.

\section{Las Rentas Extraordinarias}

Bajo el título de "Recibo extraordinario", en el libro de Obra, se registraban los ingresos de la Obra y Fábrica procedentes de circunstancias que estaban fuera del desarrollo habitual o común de la actividad económica que desempeñaba este perceptor de rentas de la catedral.

Los ingresos extraordinarios, tal como era de esperar, constituía la partida de menor cuantía de las que componían el cargo de la cuenta de la Obra. Bajo este título se encontraban importes por conceptos de diferente naturaleza. Si atendemos al contenido de los asientos registrados bajo este título en el libro de Obra de 1536-1537 (A.C.T, OF831, fol.8r-9r), podemos estipular una aproximación a las dimensiones y extensión de esta partida. Así, entre los elementos que componían el recibo extraordinario de este ejercicio, encontramos importes tan diversos como los que se refieren a ingresos por jubileos, por material entregado o donado a la Obra de forma extraordinaria y que se registraba en este cargo por el valor de tasación del mismo, cantidades por capas de diferentes canonjías, bulas, más mandas testamentarias, limosnas, etc.

Por otro lado, y en relación al contenido a esta partida extraordinaria en algunos libros de Obra, bajo este concepto encontraba incluido el importe de otras mandas, demandas y limosnas no registradas en el título anterior que expresaba este concepto.

Concluye aquí lo relativo a las diferentes fuentes de ingresos con las que contaba la Obra y Fábrica de la Catedral de Toledo, y que 
constituía la base financiera sobre la que se cimentaba su actividad. Por otro lado, y en base a la información extraída de los libros de cuentas, se pueden hacer una serie de consideraciones generales, lejos de pretender dar conclusiones económicas exhaustivas al respecto. En este sentido, podemos decir que en función a una visión general de la institución podemos determinar que aproximadamente del total de maravedíes que conformaba el cargo de la Obra y empleado en atender su actividad anual; aproximadamente un $85 \%$ procedía de la recaudación efectiva de excusados y terzuelos del año corriente. Este porcentaje no considera lo obtenido de la copia de los excusados de la ciudad, que venía a constituir alrededor de un $2 \%$ del importe total de los ingresos. Por otro lado, el retraso en el cobro de éstas rentas en ocasiones hacía que esta cantidad aumentara algo más al unirse estas cantidades a la recaudación del año corriente. Con estas circunstancias, es de recibo afirmar que los ingresos procedentes del cobro de los diezmos de excusados de Obra y terzuelos, venían a sostener básicamente la actividad de la Obra. A pesar de esta particularidad, no se puede subestimar las cantidades obtenidas de los arrendamientos y tributos de las posesiones adscritas a esta institución, que suponían aproximadamente el $5 \%$ del monto total; la partida que contenía los ingresos por mandas y demandas ordinarias, un 2,5\%; las rentas de aliceres, 2,5\%; y por último, el resto de la financiación procedía de las cantidades correspondientes al recibo extraordinario, que rondaba en torno al $3 \%$, aunque dada su naturaleza la oscilación era impredecible.

\section{LOS EMPLEOS DE LAS RENTAS}

Una vez efectuada la recaudación, y tal como correspondía a las funciones propias de cualquier receptor, cabía al de la Obra en este caso, satisfacer las cantidades que cupieran a cada uno de los asalariados de la Obra y Fábrica, así como los gastos vinculados a este organismo. De la suma de estos importes, gastos por salarios y gastos de funcionamiento de Obra de muy diversa condición y naturaleza; surgía el importe total del descargo, concepto contable que veremos reflejado en los denominados libros de Obra.

\section{Los gastos por salarios vinculados a la Obra y Fábrica}

El pago de los salarios de la Obra y Fábrica correspondía al receptor, que los hacía efectivo atendiendo a las sucesivas copias o nóminas 
elaboradas por los contadores en función de las anotaciones de las asistencias y ausencias, y según la periodicidad prescrita para cada uno de los oficios.

Entre las partidas de gastos por remuneraciones, cabe hacer mención a los salarios de los encargados de labores puramente de gobierno y administración: al Obrero, que recibía este importe por tercios en orden a dirigir la Obra y Fábrica; a los visitadores, por su asistencia en las labores de asesoramiento al obrero y participación en la dirección y gobierno; a los procuradores, por la asistencia jurídica; al receptor de la Obra ${ }^{14}$, encargado del manejo de las rentas; el escribano de la Obra, por dar fe de los actos; a los letrados, que venían a recibir su salario de este organismo por las diferentes labores de asesoramiento jurídico; al secretario del cabildo, por estar presente en las posesiones de cargos y nombramientos y en la toma de cuentas; y al notario del cabildo, pagados por tercios "...porque rreside en tal ofiçio de la escriuania...". En relación a estos dos últimos diremos que recibían por sus servicios remuneraciones de los organismos, Obra y cabildo. En el mismo sentido, lo hacían el deán que recibía, además de la asignación del cabildo, su retribución de la Obra en razón de la administración del coro y por celebración de las fiestas principales; el Capiscol, que tomaba 30 fanegas de trigo y 30 de cebada, pagadas al precio que valiesen en la alhondiga de Toledo, por el día de la Virgen de Agosto y 3 días antes.

Aparte de retribuir a alguno de sus miembros directos, la Obra y Fábrica hacía transferencia al cabildo, al que se le "auian de auer", de ciertas cantidades procedentes de las rentas de la Obra, y que se hacían efectivas al refitor ${ }^{15}$ en su nombre. Esta cantidad se reconocía con una periodicidad anual, llegando a alcanzar en la primera mitad del siglo XVI, 7.500 maravedíes. Este importe tenía su justificación en: los 4.500 maravedíes a los que debía hacer frente la Obra por unas casas que se derribaron delante de las casas arzobispales; y los 3.000 maravedíes de las casas que también corrieron la misma suerte en la Puerta Nueva. La totalidad de dicho importe, como hemos señalado, correspondía al cabildo, y por éste se encargaba de recibirla el refitolero de manos del receptor de la Obra al que el obrero daba cédula para que hiciese el pago.

\footnotetext{
14 El cobro se le realizaba en una sola paga que correspondía con el último tercio.

15 El refitor, al mando del cual se encontraba el refitor o refitolero, era el organismos encargado del manejo de las rentas procedentes de la denominada mesa capitular.
} 
Con las rentas de la Obra, igualmente, se financiaba la Cátedra de Teología, que recibía una remuneración por tercios; se pagaba a los cantores, a los que se entregaba igualmente un importe consignado en los libros de cuentas como cantores por distribuciones; a la voz contrabajo; a los tenedores del coro y músicos; al maestro de capilla; al músico de sala; al organista; al maestro de órganos; y al entonador de órganos. Cada dos meses se entregaba también el importe correspondiente a los menestriles, encargados de tocar en algunas funciones religiosas. A ellos se destinaba también una partida para ayuda de costa de menestriles.

Junto a los diferentes miembros del coro y músicos, figuraban en los descargos o gastos los importes entregados a otros personajes vinculados a la labores de culto de la Iglesia catedral, como los clerizones; los oficiales de la Iglesia: sacristanes del sagrario, que además de su salario recibían una cantidad por encender el carbón para el brasero de los presentes; los sacristanes del antigua, por dar recado a los capellanes que decían misa en los altares de Nuestra Señora del Pilar y la Antigua; a los sacristanes "...que estan donde dizen misa los señores canónigos"; al maestro de ceremonias, encargado de dirigir el protocolo; y al maestro de clerizones, por componer la sibila la noche de Navidad.

Junto a los salarios y las retribuciones mencionadas hasta el momento, la Obra debía hacer efectivas las cantidades a otros tantos personajes relacionados con la ornamentación, construcción y mantenimiento del templo. Relacionado con este objeto, están los importes reconocidos al maestro de obras, por todos los días que visitase las obras de la iglesia, según copia; al maestro de vidrieras, encargado del adobo de las vidrieras de las ventanas altas y bajas de la iglesia de Toledo y de otras capillas que eran de responsabilidad de la Obra; y así como herreros, bordadores, pintores, brosladores y plateros.

En los pagos por salarios, además de los profesionales que mantenían una relación vinculante de carácter habitual, se puede hablar de otros que ejercían su actividad de forma temporal o a jornal, entre ellos los que aparecían como bordadores a jornal, pintores a sueldo de la Obra, herreros, operarios a los que se hacía encargo de la reparación de vidrieras a destajo o destajos de piedra labrada, etc.

Otros oficios y cargos vinculados a las labores de la Obra y Fábrica, y que generaban salarios por funciones de mantenimiento eran: el clavero, responsable de la guarda y mantenimiento de los materiales y los elementos de culto; el barrendero al que cabía adecentar las capillas; el 
perrero, que sacaba los perros del templo; el alcaide de la torre; el guarda de las puertas de la iglesia, que, según se recoge en la contabilidad, se ocupaba de guardar las puertas de la iglesia para que no entrase ninguna persona cargada por ella, ni furgón, ni hubiese ruidos ni personas atravesando el templo mientras estuviesen en el coro; el guarda para la noche, el guarda del coro, por apuntar las faltas que se hacían en el coro; el guarda de la librerías, ocupado en tener cargo de que la librería estuviese limpia y abierta cuando fuese menester; el lamparero encargado de la iluminación; el campanero, afanado en el cuidado de las campanas; el relojero que recibía su salario por mantener "concertado" el reloj; el cerero; el que enciende la cera y la cuenta referida al salario del que da cera y aceite.

\section{Gastos corrientes y extraordinarios de la Obra y Fábrica}

Además de los gastos del personal mencionados, podemos hacer referencia a las partidas de gastos vinculados al desenvolvimiento del objeto social de la Obra y Fábrica. En principio, en relación a los gastos referidos propiamente a la Obra ${ }^{16}$, derivados de la compra de materiales, podemos hacer mención a las partidas compradas periódicamente de: cal y yeso, teja y ladrillo, piedra blanca y berroqueña, hierro y acero, mármol de filabrés, alabastro, jaspe, madera, cáñamo y esparto, cobre y estaño, oro, seda, plata brocada y otro materiales destinados a labores de construcción, aderezo y mantenimiento del templo.

Además, junto a los gatos de compra de estos materiales, figuran los vinculados a los empleos o encargos de dorar y pintar, de iluminar libros, de escribir libros, dorar pulpitos y puertas de bronce, copias de los doradores, copias e oficiales y precios y gastos del sagrario.

Relacionadas con el mantenimiento y reposición de los utensilios y elementos necesarios para el culto, y vinculados a labores puramente de la Fábrica, figuran partidas sobre gastos de ostias y vino para las misas de los coros, ostias y vino para las misas de las capillas, para llevar la cruz en las procesiones, de palmas de Elche, de cera y aceite, de

16 Estas cuentas de gastos relativas a la Obra eran las que contenían mayores diferencias en las partidas de un año a otro, debido a las lógicas diferencias de movimientos que se observaban en virtud a las necesidades que podían ir surgiendo de materiales en relación a la Obra, a diferencia de lo que pudiera ocurrir con los asalariados. 
poner los libros en el coro, de tonar los órganos, de afinar los órganos, de lavar la ropa del sagrario, de lavar la ropa de las capillas, de poner los libros en el coro, de hacer decir las misas de la antigua, mantenimiento de los seises, el pan de los seises, cera comprada y aceite.

Conjuntamente a todos los conceptos hasta aquí mencionados, que suponían el grueso de los gastos a los que debía enfrentarse la Obra; encontramos los denominados gastos por menudo de diferente naturaleza o puntuales y de menor cuantía procedentes de: agua que se echaba en el aljibe del Sagrario, por el gasto que importaron dos columnas que se pusieron en el púlpito y un capitel que llamaban del Evangelio, por ciertas cantidades que se compraron de plomo, etc.

En otro orden de cosas, a la Obra y Fábrica se le achacaban ciertas labores de asistencia o beneficencia, a lo que se destinaban de forma frecuente importantes cantidades de dinero que figuraban en el descargo de los libros de Obra. En este caso, aparecían referidas a esta labor, partidas específicas de dinero destinadas a ayuda a niños de la piedra, pan para limosna y pan cocido de limosna del claustro. En esta última cuenta, figuraban las cantidades de fanegas de trigo para limosna de pan cocido que se repartía tal como venía siendo costumbre a costa de la Obra en el claustro de la catedral. Dicho importe en 1537 llegó a suponer un total de 20.050 maravedíes, que fue lo que se pago por 200 fanegas de trigo (A.C.T, OF-831, fol.71). Por otro lado, esta partida era frecuente entre los gastos de los libros de Obra de cada año, aunque en algunos, a pesar de ser mencionada, aparecía en blanco.

Otro de los descargos que figuran en el libro de Obra lo constituía una transferencia que se hacía efectiva al beneficiado de la Iglesia de San Román, como consecuencia del tributo de unas casas que se derribaron para hacer unas obras encima de la bóveda.

Finalmente, como partidas de gastos figuraba la parte del subsidio extraído de las rentas de la Obra y Fábrica para satisfacer a la corona y que correspondía a este perceptor de rentas de la Iglesia de Toledo, según las asignaciones previas hechas por los contadores.

En la parte final del libro de Obra se contenían los libramientos, entre los que figuraban órdenes de pago dadas por el obrero al receptor por los diferentes gastos: atender los gastos de la fiesta del Hábeas, sacar los gigantes, tañer vihuelas de arco, vestimentas para los asalariados de la Obra y Fábrica, ayuda para costas y gastos de capas, 
almuerzo de los capellanes, vestir a los seises, capas de los seises o capas del obispo, etc.

\section{LA ORGANIZACIÓN ADMINISTRATIVA}

En principio, y tal como venimos apuntando, el importe de los ingresos obtenidos marcaba la mayor o menor importancia de las obras acometidas en el templo. No obstante, el aparato de dirección y administrativo constituía otro instrumento clave de la actividad económica de la Obra y Fábrica. Su configuración parte del estatuto otorgado por don Pedro González de Mendoza ya el 24 de diciembre de 1490; y su objeto era poner freno a la mala gestión que el Obrero y los oficiales venían desempeñando, que había hecho que muchas personas se quedaran con sus bienes y rentas (Lop 2003: 295).

Poco cambió el organigrama administrativo de la Obra, que llegó en el siglo XVI, prácticamente en similares circunstancias. Así, entre estos cargos y oficios vinculados a diferentes actividades de gobierno, administrativas y de representación, cabe hacer mención, en principio, al obrero mayor o canónigo obrero, los visitadores de la obra, el receptor general, el escribano, etc. Estos cargos eran elegidos en sesión capitular y obligaban al elegido a aceptar el nombramiento, pues en caso contrario eran expulsados del coro por seis meses (Ibidem: 296).

Tras la aceptación, el elegido juraba el cumplimiento ante el cabildo y se sometía expresamente a las condiciones que se venían sometiendo sus antecesores, tal como se detalla en los documentos.

La actividad administrativa de la Obra se vivía en la Obrería, que tenía su ubicación en la catedral en unas oficinas situadas por debajo de la sala capitular:

Bájase á las oficinas de la Obra (que como tenemos dicho se encuentra en el piso inferior de la sala y antesala capitular) por una estrecha escalera, cuya puerta, pequeña y chapada de hierro, se halla al salir de dicha sala á la izquierda del atrio ó bóveda que fue antiguamente capilla de Santa Isabel. Está su hueco dividido en cuatro secciones, sirviendo la primera, en que remata la escalera, de despacho para el Tesorero ${ }^{17}$, Contador y

17 El autor reconoce como tesorero al receptor, al que da la denominación, precisamente, de Tesorero receptor (p. 647). 
ayudante; la segunda es en la que tiene el suyo el Canónigo obrero,.. (Sixto Ramón Parro 1857: I, 647-8)

Sin duda era el canónigo obrero u Obrero la figura más representativa de la Obra, en él recaía por delegación la responsabilidad del gobierno y la dirección de dicho organismo. Al Obrero se le responsabilizaba de la administración de su hacienda, aunque sus funciones iban desde la toma de decisiones relativas a la gestión, supervisión y control, tanto de las rentas, como del personal directa o indirectamente a través de delegados; hasta las labores de representación de la institución ante los diferentes órganos de gobierno de la Iglesia de Toledo. El canónigo obrero era elegido y nombrado, entre los canónigos, por el arzobispo con el consentimiento del cabildo. En las labores de dirección el obrero se veía asistido y aconsejado por dos visitadores nombrados por el arzobispo a tal efecto.

El obrero se responsabilizaba de las cuestiones que afectaban a la gestión de la Obra y Fábrica; y en el momento de su nombramiento, recibía de su predecesor el informe sobre el estado actual de la gestión y las cuentas de la Obra, que se realizaban cada año avanzado el mes de diciembre, tal como hemos podido comprobar de algunos documentos. Sin embargo, estaba limitado en el plano económico por las funciones del receptor de la Obra. Precisamente, en las condiciones a las que someten los receptores desde $1503^{18}$ (A.C.T, OF-799, fols.2r-3v), figuran algunas de estas limitaciones que afectan al Obrero, entre ellas, las siguientes:

- No podía rematar renta alguna sin acuerdo de los visitadores y del receptor, ni recibir puja.

- Estaba incapacitado para liberar a ninguna persona que se obligara respecto a las rentas de la Obra, aunque se diese la circunstancia de que la misma estuviese sujeta a muchas fianzas o las tomasen varias personas.

- Tenía prohibido sacar ninguna renta para sí mismo de la Obra.

18 Son precisamente las condiciones a las que se suscribe Lucas de las Peñas como receptor de la Obra en 1503-1504, las que se toman para los sucesivos receptores, aspecto al que se hace mención expresa en el documento. En este documento se advierte que estas condiciones se tomarán como obligatorias, y por esa razón son asentadas por el escribano de la Obra, según mandato, al principio del libro de Obra del año 1503-1504 (A.C.T, OF-799, fols.2-3v). Igualmente, tal como figura en la orden, manteniéndose en años venideros para su conocimiento. Este acto fue dado en Alcalá el 24 de enero de 1503. 
- El obrero y los visitadores no podían comprar ninguna cosa para la Obra, sin consentimiento del receptor, incluso si fuesen cosas pequeñas "...no entiendan en ello los visitadores".

- Estaba inhabilitado para actuar sobre las deudas que se tenían contraídas con la Obra. Es decir, el obrero no podía absolver a ningún excomulgado de la Iglesia por deudas con la Obra, ni dar término, sin consentimiento del receptor, a la deuda. En caso contrario de que se diera la circunstancia de que el obrero diera la absolución al deudor o pusiera fin a su compromiso; quedaba obligado a pagar la dicha deuda, y el receptor podía tomar juez cualesquiera para ir contra él, salvo cuando por sentencia se determinase que debía ser absuelto.

- Lo que el obrero librase en el receptor no podía ser mayor a 10.000 maravedíes, en tal caso, debía llevar la firma del escribano de la Obra.

- Al obrero se le impedía cobrar ninguna cosa de las rentas de la Obra, obligación que correspondía al receptor.

El Obrero estaba asistido en sus tareas de gobierno por los visitadores de la Obra nombrados por el prelado para tal fin. En este sentido, la labor de los visitadores se puede entender de supervisión y control de la gestión de la Obra y Fábrica, función que desempeñaban en nombre del prelado.

Por lo que cabe a las funciones de garantía y representación de los actos ejecutados en nombre de la Obra, éstas cabían al escribano, encargado de dar fe de las escrituras y demás actos que pasaban por él, tocantes a este organismo. A su oficio estaban vinculadas un conjunto de funciones concretas, entre las que se encontraban, auxiliar al obrero en las funciones relativas a supervisar el adecuado suministro en el mantenimiento del templo; asistir, junto con los visitadores, a la inspección de la Obra, de la que tomaba cuenta por escrito; formalizaba los documentos relativos a las obras y a los pagos de los asalariados; hacía las copias de las rentas; se encargaba de los apuntes contables en el libro de obra; y estaba presente en la toma de las cuentas al receptor. Por estas funciones, tal como se recoge en los libros de Obra, se le reconocía un salario anual que "a de auer" y que hacía efectivo el receptor de la Obra. 
En la Obrería prestaba sus servicios el contador, obligado a asistir a la contaduría de la dicha Obra, durante la mañana y la tarde, en el tiempo del coro, para resolver todos las cuestiones correspondientes a la misma (Santolaya Heredero 1979: 29). El contador elaboraba las copias de los oficiales y peones que se formalizaba en la escribanía, atendiendo a los apuntes de asistencia que le facilitaban. En virtud a estas copias el receptor de la Obra hacía efectivos los salarios y jornales.

Finalmente, la Obra y Fábrica de la catedral en las labores de gestión y administración se encontraba auxiliada por el notario y el secretario del cabido del que como hemos visto recibía una remuneración. El notario y el secretario, como veremos más adelante, también estaban presentes en la toma de cuentas al receptor.

Las labores de recaudación de las rentas y empleo de las mimas, correspondían al receptor de la Obra. El receptor de la Obra se comprometía, una vez nombrado en sesión capitular, al cobro de los excusados de la Obra, junto a las demás rentas, para lo cual debía presentar fianza a consentimiento del obrero y los visitadores.

Aceptadas las fianzas, el receptor procedía al cobro de las rentas de la Obra. En este sentido, en el libro de Obra de 1501-1502 (A.C.T, OF-797) el cargo hace mención a la obligación del receptor de la Obra, Pero Sánchez de Madrid, de los maravedíes que

...ovo de reçebir e de recabdar en nombre de la santa Iglesia e para ella asy de las rentas de los escusados de la dicha Obra como de los heredamientos y posesiones e mandas e demandas e en otra qualquier manera a la dicha Obra debidas e pertenecientes...

Estas cantidades recaudadas lo eran del año de 1501 "...que se acostumbran a cobrar e gastar en el anno de mil e quinientos e dos annos".

En relación al empleo de las rentas, si atendemos a las investigaciones de Laura Santolaya (1979: 28), el receptor general adelantaba del dinero de la Obra y Fábrica lo necesario para hacer frente a los gastos que importaba la recaudación. Cantidades que, según la misma autora, restablecía posteriormente de los ingresos, obligándose personalmente a la devolución, lo que originaba, en ocasiones, la incorporación a la Obra y Fábrica de bienes inmuebles procedentes del patrimonio personal del receptor para hacer frente a la deuda contraída.

Además del cobro y la responsabilidad en el empleo de las rentas, del cargo de receptor emanaban otras responsabilidades. Así, desde 
1503, en virtud a las condiciones a las que suscribió el receptor Lucas de las Peñas, el receptor de la Obra estaba obligado concretamente a (A.C.T, OF-799, fols.2r-3v):

- Tomar a su cargo, sin dar descuento ninguno, la renta de las posesiones pertenecientes a la Obra y Fábrica, excusados, tributos, aliceres, mandas y demandas, de cada año. Las copias de estas rentas eran elaboradas por el escribano de la Obra, por lo que este mismo venía a cobrar de salario 35.000 maravedíes. Además, el receptor no estaba obligado a sanear las quiebras correspondientes a las rentas, pero sí tenía el deber de abrir contra ellas las diligencias oportunas en beneficio de los intereses económicos de la Obra. En este punto, si no había bienes y personas para ir contra los dolosos, al receptor se le había de recibir la quiebra.

- En caso de que se diese a alguno de los arrendadores la suspensión de las rentas por algún tiempo de alguna deuda, sin mandar que el receptor tomase fiadores de ella; la suspensión realizada era recibida en cuenta.

- El receptor debía tomar fianza de las rentas que fuesen rematadas en el "vanco" a consentimiento del mismo.

- El receptor debía pagar los salarios de los oficiales de la Obra y también los destajos, estando obligado a tener cuenta con todos. Además, debía obligarse a pagarlos a tiempo y según la obra que hubiese realizando, evitando pagar a ninguno por adelantado y a los oficiales de la Obra, salvo si el obrero mandase que se les pagara por alguna causa o circunstancia especial.

- En caso de efectuarse alguna compra para la Obra, el receptor no debía efectuar el pago antes de que la compra fuese entregada y sin que el escribano entendiese de ello.

- Todo lo que se librase por cédula firmada del obrero y del escribano de la Obra, de mayor suma como de menor que por ella se hubiese pagado, el receptor lo debía recibir en cuenta al tiempo en que correspondiese hacerla. Esta cláusula se le mandaba notificar también al contador para que pudiese guardar todo lo capitulado.

- En cada año al principio del mes de enero, el receptor estaba obligado a fenecer ante el obrero y los visitadores la cuenta de las rentas, antes de que fuese mandado en nombre del arzobispo de Toledo. De esta forma, se procedía a determinar, por el cierre de la 
cuenta al receptor, la cantidad por la que el mismo fuese alcanzado. En caso de que, al hacer la cuenta, hubiese cantidades en "dudas", es decir, que llegado el vencimiento de la deuda, ésta no hubiese podido ser cobrada por el receptor, se procedía a conceder al mismo un plazo de un año para que se acabase de recaudar y se pagase a la Obra.

Debido a su implicación en el manejo, cobro y empleo, de las rentas de la Obra y Fábrica; en el receptor recaía el mayor peso de la actividad económica y, por ende, de la contable. Efectivamente, en primer lugar y fruto de estas funciones, el receptor se veía en la necesidad de llevar registro diario de todos los ingresos, gastos, derechos de cobro y obligaciones de pago que iban surgiendo al hilo de sus cometidos al frente de la receptoría. Este hecho lo atestiguan algunos de los manuales que se conservan en el Archivo Capitular de Toledo. El método contable aplicado en estos manuales atendería así a los conocimientos registrales del tenedor. En este punto, conviene señalar que, precisamente, uno de estos manuales conservados, acompañado de su mayor, constituye la primera muestra de contabilidad por partida doble localizada hasta el momento para una institución eclesiástica. El manual y mayor en cuestión pertenece al receptor de la Obra, el racionero Gutierre Hurtado, y corresponde a $1535-1536$.

Además de la contabilidad diaria que pudiera llevar el receptor de rentas, para la Obra y Fábrica se prescribía la teneduría del libro de Obra, donde se asentaban detalladamente los ingresos y gastos que afectaban a este organismo. La teneduría de este libro de Obra se aprobó en capítulo el 5 de marzo de 1493, para mejor control de lo tocante a la Obra, obligando a asentar en él cada cuatro meses todos los gastos (Lop 2003: 296-7).

De la misma manera, fruto de sus implicaciones económicas en este organismo catedralicio, el receptor de la Obra estaba obligado a presentar cada año la cuenta y razón de su gestión ante la dirección, el obrero mayor, en presencia de los visitadores, el notario y el secretario del cabildo. Esta cuenta, localizada en los últimos folios del libro de Obra, era tomada por el contador, encargado también de tomarla a cuantos personajes estuviesen implicados en el manejo de las rentas vinculadas a esta entidad, con la periodicidad prescrita al receptor. 
La toma de la cuenta tenía carácter anual, y el soporte utilizado era, como venía siendo habitual para este tipo de operaciones, y tal como hemos señalado más arriba, la carta cuenta. En la carta cuenta se daba cumplido detalle de los ingresos y gastos en forma de cargo, que contenía los ingresos procedentes de las rentas; y el descargo, donde se tomaban los gastos. Mientras que el cargo se hacía en contra del receptor, el descargo operaba a favor del mismo. Por diferencia de los dos montantes, cargo y descargo, se calculaba el alcance o resultado, que actuaba a favor o en contra del receptor ${ }^{19}$. Es decir, si el cargo era mayor al descargo, el alcance lo era en contra del receptor de la Obra; y si por el contrario era menor, actuaba a favor.

El contador completaba las partidas de cargos y descargos con la información que les proporcionaba el receptor de la Obra de su actividad a lo largo del año. Esta información provenía a su vez, suponemos, de los registros diarios que realizaba el mencionado receptor. En el ejercicio de sus responsabilidades, el contador en caso de encontrar alguna partida injustificada o sujeta a error, tenía potestad para realizar los tramites necesarios para su resolución que dejaba en manos, en tal caso, del agente, sobre el que recaía la autoridad para salvar los pleitos que atañían a la Obra y Fábrica. Este personaje se encontraba asistido, a su vez, en el ejercicio de sus funciones por una serie de procuradores y abogados laicos.

Finalmente, era obligación del contador de la Obra y Fábrica hacer la cuenta a diferentes cargos, vinculados a la actividad diaria de la institución y responsabilizados en el manejo de bienes y rentas de este organismo. Así, en el libro de Obra se integraba la cuenta y razón que se toma al tenedor de materiales, encargado de la recepción y entrega de los materiales que le pedía el aparejador, y cuyo movimiento debía preocuparse de llevar perfectamente anotado; la del clavero, empleado en

19 Si bien a lo largo de todo el siglo XVI el cargo y descargo se toma a favor y en contra, respectivamente, del receptor; en el libro de Obra del año 1499-1500, este cargo y descargo se hace al obrero, tal como se expresa en el encabezamiento del cargo (A.C.T, OF-795, fol.1r):

Relacion del cargo de todos los maravedis que el señor Alvar Perez de Montemayor, canonigo en la Santa Iglesia de Toledo, ovo de resçebir e recabdar en nombre de la Obra de la dicha santa Iglesia e para ella como obrero della asy de las rentas de los escusados de la dicha Obra como de los heredamientos e posesiones della e mandas e demandas o en otra qualquier manera a la dicha Obra debidos e pertensçientes este anno del Señor de mill e quatrocientos e noventa e nueve annos que se acostumbran cobrar e gastar en el anno siguiente de mill e quinientos annos. 
proveer a la Obra de materiales y al que periódicamente se le entregaban ciertas cantidades para tal fin; y la del mayordomo de la cera, ocupado de la compra y distribución de la cera y aceite que se consumía, de lo que debía dar justificación y, además, satisfacer el alcance que resultaba de la misma.

\section{DOCUMENTOS}

1459-1479- "Relaçion de las debdas de los escusados de la Obra de la Santa Yglesia de Toledo...", A.C.T, OF-363.

1499-1500- Libro de Obra, A.C.T, OF-795.

1501-1502- Libro de Obra, A.C.T, OF-797.

1503-1504- Libro de Obra, A.C.T, OF-799.

1534-1538- Libro de Obra de la Iglesia de Toledo, A.C.T, OF-829.

1535-1536- "Año de MDXXXV. Obra. Gastos de MDXXXVI", A.C.T, OF-830.

1536-1537- "Año de MDXXXVI. Obra. Gastos de MDXXXVII", A.C.T, OF-831.

1536-1549- "Registro de las rentas de los escusados de la Santa Iglesia de Toledo de los frutos de los años...", A.C.T, OF-366.

1542-S.XVIII- "Libro Manual de las cosas que son cargo de los ministros del Cabildo y como se arriendan sus possessiones", A.C.T, OF-909.

\section{BIBLIOGRAFÍA}

ALCOCER, Pedro de (1554) Hystoria, o Descripcion de la Imperial Çibdad de Toledo. Con todas la cosas acontecidas en ella, desde su principio, y fundacion. Adonde se tocan, y refieren muchas antiguedades, y cosas notables de la Hystoria general de España. Agora nueuamente impressa. Por luan Ferrer, Toledo. Edic. Facsímil: Toledo, IPET, 1973.

FERNÁNDEZ COLLADO, Ángel (1997) "La limosna del pan del claustro en la catedral de Toledo", Memoria Ecclesiae, núm. XI, Oviedo, pp. 237-241.

- (1999) La Catedral de Toledo en el siglo XVI, vida, arte y personas. Toledo: Diputación Provincial de Toledo.

- (2000) "Grupos de poder en el Cabildo toledano del siglo XVI", en Sociedad y Élites Eclesiásticas en la España Moderna, coord. Fco. José Aranda Pérez. Cuenca: Ediciones de la Universidad de Castilla-La Mancha, pp.149-162. 
GonzÁlez FerRando, José María (1998) "El Libro de Ferias. Análisis de un Instrumento Contable Básico en la Organización de la 'Cuenta y Razón' de los Mercaderes Castellanos en el siglo XVI", Técnica Contable: La Contabilidad en el siglo XXI, Volumen Extraordinario con motivo de cumplirse el L Aniversario de la Revista "Técnica Contable", Madrid, pp. 377-397.

IZQUIERDO BENITO, Ricardo (1981) "Bienes, ingresos y gastos de la Obra de la catedral de Toledo durante la primera mitad del siglo XV", España Medieval II, pp. 467-484.

- (1982) Precios y salarios en Toledo en el siglo XV, Fundación Juan March, Serie Universitaria.

- (1980) "El Patrimonio Urbano del Cabildo de la Catedral de Toledo durante la segunda mitad del siglo XIV", Anales Toledanos, núm.XIII, Diputación Provincial de Toledo, Toledo, pp. 3-24.

- (1997) "Edad Media", VV.AA., Historia de Toledo. Toledo: Ed. Azacanes, pp. 149-256.

LADERO QUESADA, Miguel Ángel (1967) La Hacienda Real Castellana entre 1480 y 1492 . Universidad de Valladolid, Facultad de Filosofía y Letras, Departamento de Historia Medieval.

- (1975) La Hacienda Real para una imagen de Castilla, (1429-1504). Valencia.

- (1982) El Siglo XV en Castilla. Fuentes de renta y Política Fiscal. Barcelona: Ed. Ariel Historia.

LOP OTín, Ma José (1995) "El siglo XII en la historia del Cabildo Catedral de Toledo", Actas del Congreso Internacional Conmemorativo del VIII Centenario de la Batalla de Alarcos, Ciudad Real, pp. 473-493.

- (1996) "Fuentes Medievales para el estudio del Cabildo Catedral de Toledo", La investigación y las fuentes documentales de los archivos, ANABAD Castilla-La Mancha, Asociación de Amigos del Archivo Histórico Provincial, Guadalajara, pp. 789-800.

- (1997) "La Labor Cultural y Educativa del Cabildo Catedral de Toledo a fines de la Edad Media", Ensayos Humanísticos: Homenaje al Profesor Luis Lorente Toledo, coordinador: Rafael Villena Espinosa, Cuenca: Ediciones de la Universidad de Castilla La Mancha, pp. 249-272.

- (2001) "La Catedral Medieval en sus Archivos. Estado de la Investigación", V Jornadas de Castilla-La Mancha sobre investigación en Archivos, Iglesia y Religiosidad en España, Guadalajara. 
- (2003) El Cabildo Catedralicio de Toledo en el siglo XV: Aspectos Institucionales y Sociológicos. Madrid: Fundación Ramón Areces.

MARÍN LóPEZ, Ramón (1998) El Cabildo de la Catedral de Granada en el siglo XVI. Granada: Universidad de Granada, Estudios Históricos, Crónica Nova.

MARTín GAMERO, Antonio (1862) "Toledo austriaca y borbónica", Historia de la ciudad de Toledo, Vol.ll. Toledo: Imprenta de Severiano Lopez Fondo.

MARTINEZ GIL, Fernando (1997) "El Antiguo Régimen", Historia de Toledo, Ed. Azacanes, Librería Universitaria de Toledo, Toledo, pp. 259-444.

PISA, Francisco de (1605) Descripcion de la Imperial Civdad de Toledo, y Historia de sus antiguedades, y grandeza, y cosas memorables que en ella han acontecido, de los Reyes que la han señoreado, y gouernado en sucession de tiempos: y de los Arçobispos de Toledo, principalmente de los mascelebrados. En Toledo por Pedro Rodríguez, 1605. Edic. Facsímil, Toledo, IPIET, 1974.

QUESADA SÁnChEZ, Francisco Javier (1995) Fundamentos de Contabilidad, Imprenta Tebar Flores, S.L, $3^{\text {a }}$ edición, Albacete.

RAMÓn PARRo, Sixto (1973) Toledo en la mano, Facsímil de la Ed. S. López Fando, Toledo, 1857, 2 vols, Toledo, IPET.

Santolaya Heredero, Laura. (1979): La Obra y Fábrica de la Catedral de Toledo a finales del siglo XVI. Toledo: Ed. Patrocinada por la Caja de Ahorro Provincial de Toledo.

SAntos Vaquero, Ángel; VAquero Fernández-Prieto, Emilio (1999) Fantasía y Realidad de Toledo. Toledo: Ed. Azacanes.

Torroja Menéndez, Carmen; SAnChez Palencia, Almudena (1977) Catálogo de Archivo de Obra y Fábrica de la Catedral de Toledo, Tomo 1. Toledo: Publicaciones del Instituto Provincial de Investigaciones y Estudios Toledanos, Diputación Provincial de Toledo. 